ББК 28.4

\title{
HALOPHILIC MICROORGANISMS FROM SALINE WASTES OF STAROBIN POTASH DEPOSIT
}

\author{
Nikolay Ivanovich Naumovich \\ Researcher, Laboratory of Relationships of Soil Microorganisms and Higher Plants, \\ Institute of Microbiology, NAS of Belarus \\ microbio@mbio.bas-net.by \\ Kuprevicha St., 2, 220141 Minsk, Republic of Belarus
}

\section{Aleksandra Antonovna Fedorenchik}

Candidate of Agricultural Sciences, Senior Researcher,

Laboratory of Relationships of Soil Microorganisms and Higher Plants,

Institute of Microbiology, NAS of Belarus

microbio@mbio.bas-net.by

Kuprevicha St., 2, 220141 Minsk, Republic of Belarus

\section{Zinaida Mikhaylovna Aleshchenkova}

\footnotetext{
Doctor of Biological Sciences, Institute of Microbiology, NAS of Belarus

microbio@mbio.bas-net.by

Kuprevicha St., 2, 220141 Minsk, Republic of Belarus
}

Head of Laboratory of Relationships of Soil Microorganisms and Higher Plants,
Belaruskali company exploiting the mines since the 1960s has dumped on formerly fertile lands over $730 \mathrm{mln}$ tons of solid clay-saline wastes across the overall area of about 2 thousand hectares [8].

Salt stress negatively affects growth and productivity of farm crops. Despite adverse salinization impact, soils with high technogenic load generate microbiota capable to withstand hypersaline exposure [2]. A promising strategy 
for remediation of salinized soils envisages application of legume varieties, like alfalfa to upgrade soil fertility via atmospheric nitrogen fixation. Alfalfa salt tolerance is promoted by inoculation of selected rhizobia strains and PGPR bacteria.

The aim of the study consists in the isolation of microbial cultures resistant to soil salinization and stimulating germination and growth of alfalfa (Medicago sativa).

\section{Objects and Methods}

Salt-resistant phosphate-solubilizing microorganisms were recovered from saline wastes of Starobin deposit on solid nutrient medium in compliance with the Muromtsev guidelines [6]. Tolerance of microbial isolates to sodium-, potassium- and calcium chlorides in concentrations 3, 5, 10, 15, $20 \%$ was tested on TY medium [4]. Nitrogen-fixing Ensifer meliloti strains able to grow on TY medium containing $300 \mathrm{mM} \mathrm{NaCl}$ were isolated from nodules of alfalfa, nifH gene encoding a small subunit of nitrogenase complex was used as nitrogen fixation marker. A couple of primers nifH-1F and nifH$1 \mathrm{R}$ proved suitable for all examined samples of alfalfa-specific nodulating bacteria [7].

Growth-stimulating action of bacterial isolates under salinization conditions was evaluated using alfalfa seeds. Tested plant seeds were steeped in $2 \%$ aqueous bacterial suspension, control plant seeds were dipped into sterile tap water.

The seeds placed into vials were incubated at $28{ }^{\circ} \mathrm{C}$ during 2 hours and transferred into sterile Petri plates on damp filter paper impregnated with sodium chloride in $100 \mathrm{mM}$ concentration. The treated seeds were germinated in incubation chamber for $2-3$ days at $28{ }^{\circ} \mathrm{C}$.

\section{Results and Discussion}

Unique microflora capable to survive under extreme environmental conditions is generated in soil with high salinization and technogenic load. In this respect special emphasis is focused on microorganisms adapted to elevated mineralization background [5]. Such bacteria appear attractive due to increased biotechnological potential. They may be applied to design biopreparations remediating saline soils and effluents with complex multichemical composition of pollutants [3].

Isolation of halophilic microorganisms showing resistance to chlorides of sodium, potassium, calcium was performed from soildsaliferous wastes of Starobin potash deposit. The enrichment culture was carried out by inoculating homogenated solid saliferous wastes into selective liquid nutrient media and subsequent fermentation during 1 week. Submerged culture was conducted in $250 \mathrm{ml}$ flasks containing $100 \mathrm{ml}$ of selective medium on laboratory shaker (agitation rate $-200-220 \mathrm{rpm}$ ) at temperature $+28{ }^{\circ} \mathrm{C}$. Glucose-asparagine medium proposed by Muromtsev served as selective medium for enrichment culture of phosphate-solubilizing microorganisms. Isolates of phosphate-solubilizing bacteria were recovered by plating samples of enrichment culture on agar selective medium of the same composition.

At the next research stage isolates were screened according to the criteria of phosphatesolubilizing activity and resistance to enhanced salt concentrations. 4 cultures were sorted out of phosphate-solubilizing bacterial colonies dominating on glucose-asparagine medium with calcium phosphate. All isolates were Grampositive rods showing catalase activity, while variant $4 \mathrm{~F}$ displayed oxidase activity. Based on physiological and biochemical characterization using automatic system VITEK-2 (bioMerieux) and taxonomic nomenclature of Bergey's Manual of Determinative Bacteriology (1994) all four phosphate-solubilizing strains were affiliated to genus Bacillus.

Survival of selected bacilli exposed to the action of sodium-, potassium- and calcium chloride in different concentrations was assessed in a series of model experiments (see Table).

In accordance with the aim of our investigation strains capable to grow on media containing elevated chloride levels should be chosen as promising objects for further studies. It may be deduced from our data that 3 strains Bacillus sp. 2F, Bacillus sp. 4F and Bacillus sp. $8 \mathrm{~F}$ suit perfectly to meet the set research objectives. They may grow on media with $15 \%$ sodium-, potassium- and calcium chloride and form halo zones on glucose-asparagine medium with calcium orthophosphate, indicating conversion of added salt into water-soluble form. 
Growth of halophilic phosphate-solubilizing bacteria on TY medium in the presence of sodium-, potassium- and calcium chloride

\begin{tabular}{|c|c|c|c|c|c|c|c|c|c|c|c|c|c|c|c|c|}
\hline \multirow{3}{*}{$\begin{array}{c}\text { Isolate } \\
\mathrm{N}\end{array}$} & \multirow{3}{*}{$\begin{array}{c}\text { Control } \\
\text { (salt } \\
\text { free) }\end{array}$} & \multicolumn{15}{|c|}{ Concentration, $\%$} \\
\hline & & \multicolumn{5}{|c|}{$\mathrm{NaCl}$} & \multicolumn{5}{|c|}{$\mathrm{KCl}$} & \multicolumn{5}{|c|}{$\mathrm{CaCl}_{2}$} \\
\hline & & 3,5 & 5 & 10 & 15 & 20 & 3,5 & 5 & 10 & 15 & 20 & 3,5 & 5 & 10 & 15 & 20 \\
\hline Bacillus sp. 2F & ++ & +++ & +++ & + & + & - & ++ & ++ & ++ & + & - & +++ & +++ & + & + & - \\
\hline Bacillus sp. 4F & ++ & +++ & +++ & ++ & + & - & ++ & +++ & ++ & + & - & +++ & +++ & + & + & - \\
\hline Bacillus sp. 5F & ++ & +++ & +++ & + & - & - & ++ & ++ & + & - & - & +++ & +++ & - & - & - \\
\hline Bacillus sp. 8F & ++ & +++ & +++ & + & + & - & +++ & +++ & ++ & + & - & +++ & +++ & + & + & - \\
\hline
\end{tabular}

Note: +++- abundant growth, ++- good growth, +- satisfactory growth, -- no growth.

4 nitrogen-fixing strains of bacteria E.meliloti able to grow on TY medium comprising $300 \mathrm{mM} \mathrm{NaCl}$ were isolated from nodules of alfalfa (M. sativa).

Strain capacity to fix nitrogen mediated by nitrogenase enzyme complex was confirmed by presence of nifH gene. So far, 10 nif genes have been identified in Rhizobia, including nifH encoding a small subunit of enzyme complex. Amplification of nifH gene fragment with a couple of primers nifH-1F and nifH-1R revealed one specific zone sized approximately 430 bp (Fig. 1). Partial nifH gene amplification involving primers nifH-1F and nifH-1R demonstrated that specific PCR product available in all 4 strains of nodulating bacteria E. meliloti is identical to that of nitrogen-fixing reference strain Rhizobium loti.

A series of model experiments was conducted to evaluate growth-stimulating effect of selected halophilic phosphate-solubilizing bacterial strains on seed germination and development of alfalfa sprouts in saline media ( $\mathrm{NaCl}$ concentration $100 \mathrm{mM}$ ) (Fig. 2).

The obtained result points out the leading role of strain Bacillus sp. $8 \mathrm{~F}$ promoting germination of alfalfa seeds by $50 \%$ and elongation of seedlings by $16 \%$. The other halophilic phosphate-solubilizing bacteria Bacillus sp 2F and Bacillus sp 4F did not cause any favorable impact on germination and length of alfalfa seedlings.

Mixed influence of nitrogen-fixing strain E. meliloti $\mathrm{S} 3$ and phosphate-mobilizing culture Bacillus sp. 8F on growth and development of alfalfa crop ( $M$. sativa) in salinized enviroment ( $\mathrm{NaCl}$ concentration $100 \mathrm{mM}$ ) was tested in model experiment (Fig. 3).

The analysis of the results evidences stimulating action of strain $E$. meliloti $\mathrm{S} 3$ on alfalfa

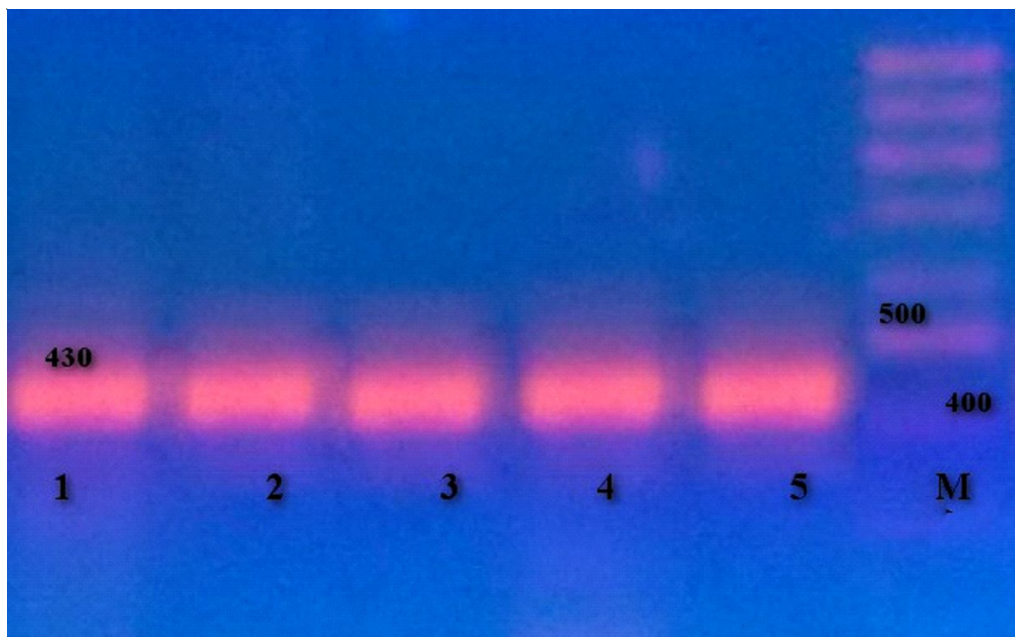

Fig. 1. Amplification of nifH gene fragment with primers nifH-1F and nifH-1R using DNA isolated from pure culture:

1 - Rhizobium loti L3 (positive control); 2 - Ensifer meliloti $\mathrm{S} 3 ; 3$ - Ensifer meliloti $\mathrm{S} 5$; 4 - Ensifer meliloti IS0; 5 - Ensifer meliloti 3583; M - DNA molecular weight marker (100 bp) 

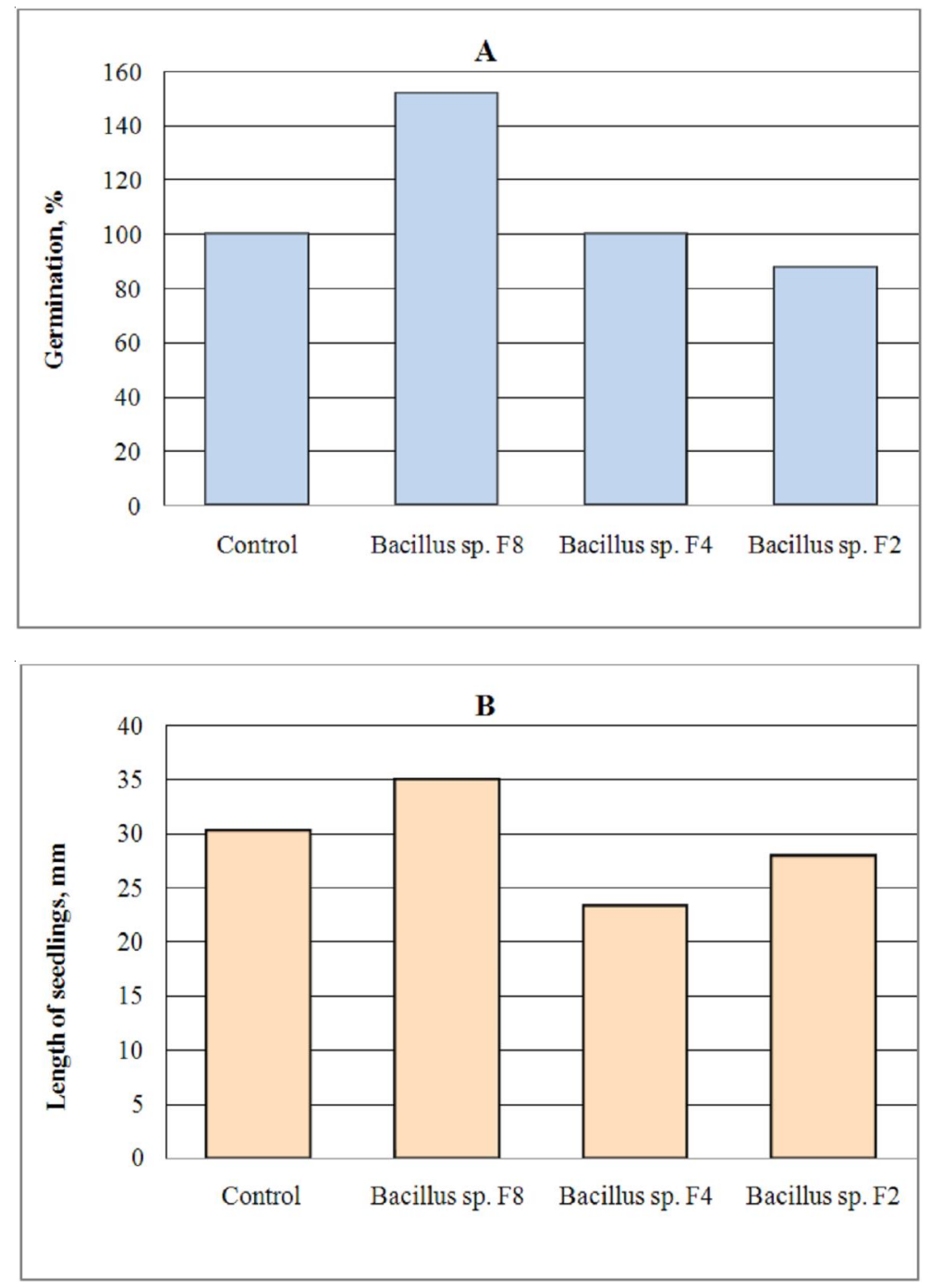

Fig. 2. Effect of halophilic strains of phosphate-solubilizing bacteria on seed germination $(A)$ and length of alfalfa seedlings ( $M$. sativa) $(B)$ under saline conditions

seed germination and development of seedlings $17 \%$ and $34 \%$, respectively. Beneficial effect on both parameters was also demonstrated by phosphate-solubilizing strain Bacillus sp. 8F. Dual application of nitrogen-solubilizing strain E. meliloti $\mathrm{S} 3$ plus phosphate-solubilizing strain Bacillus sp. 8F exposed to excessive salinity ensured increase in seed germination rate by $9 \%$ and length of seedlings by $21 \%$.

\section{Conclusion}

3 bacterial strains representing genus Bacillus and distinguished by the maximum tolerance to soil salinization and active ability to grow on media in the presence of $15 \%$ concentrations of sodium-, potassium- and calcium chloride were isolated from solid saliferous wastes of Starobin potash mines managed by Belaruskali concern.

Screening of 3 isolates for phosphatesolubilizing activity in pure culture demonstrated the ability of all selected variants to mobilize calcium orthophosphate. Strains E. meliloti S3 and Bacillus sp. 8F stimulated germination of alfalfa seeds and promoted development of Medicago sativa sprouts. The selected efficient cultures of nitrogen-fixing and phosphatesolubilizing bacteria arouse vivid interest as potential components of plant-microbial association applied in biotechnology of salinized soil phytoremediation. 

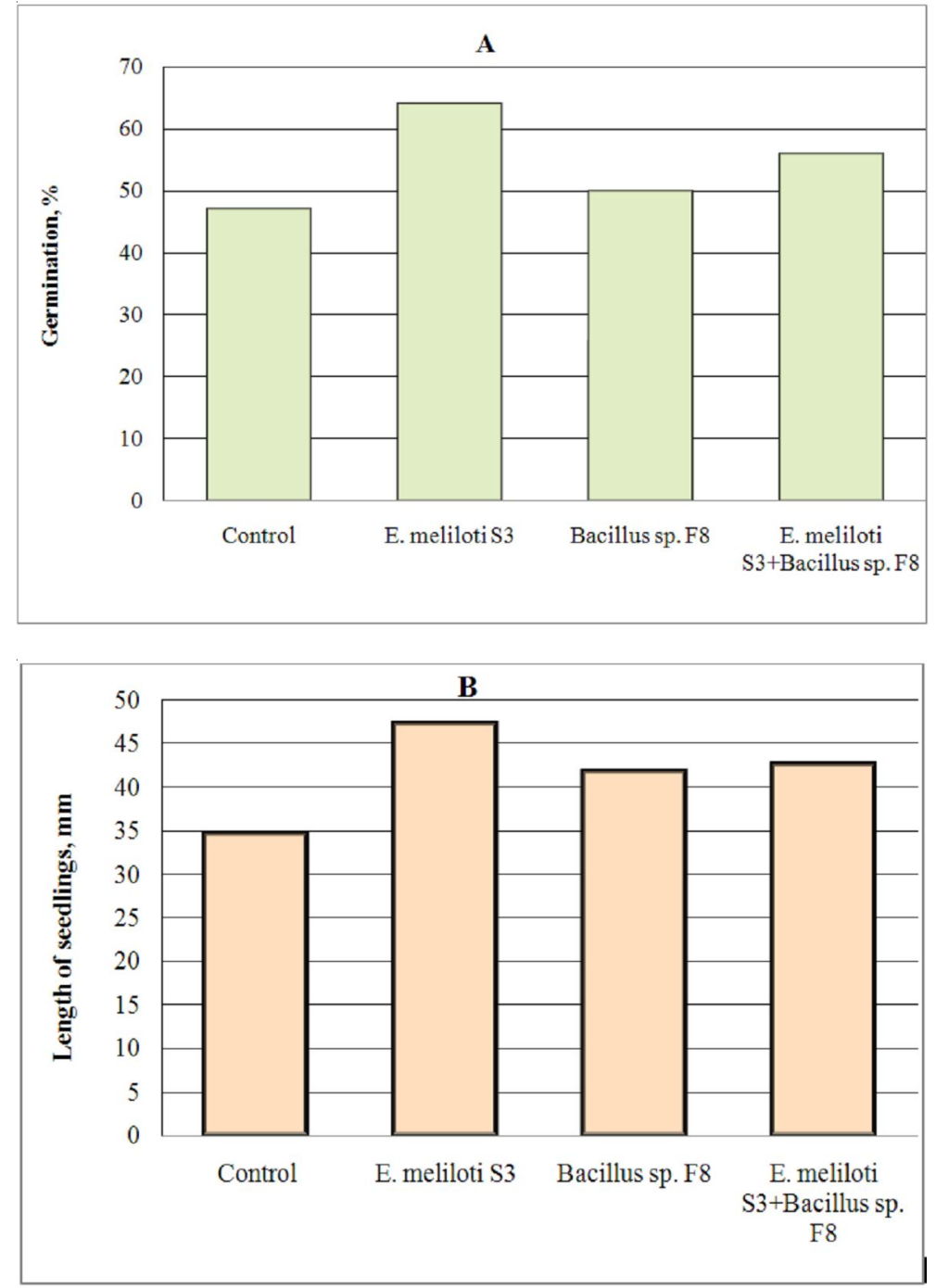

Fig. 3. Combined effect of strains E. meliloti $\mathrm{S} 3$ and Bacillus sp. $8 \mathrm{~F}$ on seed germination $(A)$ and length ofalfalfa ( $M$. sativa) seedlings $(B)$ under the salinized conditions

\section{REFERENCES}

1. Boonchan S., Britz M.L., Stanley G.A. Degradation and Mineralization of High-MolecularWeight Polycyclic Aromatic Hydrocarbons by Defined Fungal-Bacterial Cocultures. Appl. Environ. Microbiol, 2000, vol. 66 (3), pp. 1007-1019.

2. Hincha D.K., Hagemann M. Stabilization of Model Membranes During Drying by Compatible Solutes Involved in the Stress Tolerance of Plants and Microorganisms. Biochem. J., 2004, vol. 383, pp. 277-283.

3. Holt J.G., et al., eds. Bergey's Manual of Determinative Bacteriology. Williams\&Wilkins, Baltimore, Maryland, 1994. 787 p.

4. Ibrahimova M.V., et al. Symbiosis of Nodule Bacteria Sinorhizobium Melliloti with Lucerne
Medicago Sativa in the Conditions of Salinization. Microbiology, 2006, vol. 75 (1), p. 94. (in Russian).

5. Margesin R., Schinner F. Potential of Halotolerant and Halophilic Microorganisms for Biotechnology. Extremophiles, 2001, vol. 5, p. 73-83.

6. Muromtsev G.S. Main Methods of Microbiological Soil Investigations. Leningrad, AllUnion Research Institute of Agricultural Microbiology, 1987. 33 p. (in Russian).

7. Soltani Toolarood A.A., et al. Genetic Diversity and Phylogeny of Alfalfa Nodulating Rhizobia Assessed by Nif-H and Nod-A Genes. Intern. Res. J. Appl. and Basic Sci., 2012, vol. 3 (7), p. 1470.

8. Zhurman P.V., Chertko N.K. Proc. Int. Conf. Belarus State Agricultural Academy, 2007. 124 p (in Russian). 


\section{АДАПТАЦИЯ ГАЛОФИЛЬНЫХ МИКРООРГАНИЗМОВ К ЗАСОЛЕНИЮ ПОЧВЫ}

\section{Николай Иванович Наумович}

Научный сотрудник,

лаборатория взаимоотношений микроорганизмов почвы и высших растений, Институт микробиологии Национальной академии наук Беларуси microbio@mbio.bas-net.by ул. Купревича, 2, 220141 г. Минск, Республика Беларусь

\section{Александра Антоновна Федоренчик}

Кандидат сельскохозяйственных наук, старший научный сотрудник лаборатории взаимоотношений микроорганизмов почвы и высших растений, Институт микробиологии Национальной академии наук Беларуси microbio@mbio.bas-net.by ул. Купревича, 2, 220141 г. Минск, Республика Беларусь

\section{Зинаида Михайловна Алещенкова}

Доктор биологических наук, заведующая лабораторией взаимоотношений микроорганизмов почвы и высших растений Институт микробиологии Национальной академии наук Беларуси microbio@mbio.bas-net.by ул. Купревича, 2, 220141 г. Минск, Республика Беларусь

Аннотация. В работе были исследованы 3 культуры галофильных фосфат-растворимых бактерий, выделенных из калийсодержащих отходов. Было показано, что они способны расти в присутствии 10-15 \% натрия хлорида и способствовать прорастанию и росту люцерны (Люцерна посевная).

Ключевые слова: галофильные микроорганизмы, фосфаты, засоление, биотехнологии, фиторемедиация. 